\title{
Geochemistry and Mineralogy of Quarry Dusts at Some Selected Locations of Southwestern Nigeria
}

\author{
${ }^{1}$ AJIBADE, O.M. ${ }^{2}$ ADEBAYO, H.A. \\ ${ }^{3}$ OLADIPUPO, S.D. ${ }^{4}$ BALOGUN, M.S. and \\ ${ }^{5}$ ADEGOKE, C.B. \\ ${ }^{1}$ Earth Sciences Department, Olabisi Onabanjo University, \\ Ago Iwoye, ajibade.muyiwa@oouagoiwoye.edu.ng \\ ${ }^{2}$ Geography Department, Olabisi Onabanjo University, Ago \\ Iwoye, adebayooluwasegunhezekiah@gmail.com \\ ${ }^{3}$ Earth Sciences Department, Olabisi Onabanjo University, \\ Ago Iwoye, Ogun State. Seunlad50@gmail.com \\ ${ }^{4}$ Earth Sciences Department, Olabisi Onabanjo University, \\ Ago Iwoye, Ogun State. maymaymayowa@gmail.com \\ ${ }^{5}$ Earth Sciences Department, Olabisi Onabanjo University, \\ Ago Iwoye, Ogun State. boluwaii@gmail.com
}

\footnotetext{
ABSTRACT

Quarrying dusts and its environmental contamination with potentially harmful elements has been assessed with 24 composite samples differentiated into inside and outside categories and detailed interpretation was carried out using SPSS and Microsoft Excel. $\mathrm{SiO}_{2}, \mathrm{Al}_{2} \mathrm{O}_{3}, \mathrm{MgO}, \mathrm{CaO}, \mathrm{K}_{2} \mathrm{O}$, $\mathrm{Na}_{2} \mathrm{O}, \mathrm{TiO}_{2}$ and $\mathrm{Fe}_{2} \mathrm{O}_{3}$ range between $0,02-80.88 \%$. The bauxitic portions $\left(\mathrm{Al}_{2} \mathrm{O}_{3}-15.4\right)$ specify high clay percentage in the rock aggregate dust. Furthermore, $\mathrm{SiO}_{2}, \mathrm{Al}_{2} \mathrm{O}_{3}+\mathrm{TiO}_{2}$ and $\mathrm{Fe}_{2} \mathrm{O}_{3}$ ternary plot signify highly more clastic rock aggregates with the exception of Sagamu (SA) limestone quarry dust. Triangular plot of LREE-MREE-HREE indicated that the LREE were more in all the quarry dust. It also specifies elevated LREE in the limestone quarry dusts. Statistics revealed high degree contamination of Arsenic and Lead signifying likely anthropogenic inputs of these metals. Pollution Load Index values for trace metals and REE revealed Imosan, Ajebo, Kajola and Ago-Iwoye, Kajola, Ajebo and Olonde as polluted quarry sites. $\mathrm{Cu} \mathrm{Pb}$ As, $\mathrm{Ni}$ was high at Onigambari which may specify mineralization. The Chemical Index of Alteration (CIA=60.095-72.775) and the Chemical Index of Weathering (CIW=60.769-75.631) shows close relationship signifying high contents of muscovite and feldspar in the quarry dust.
} 